\title{
The Impact of Personality on Employee Innovative Work Behavior: The Case of Convection of Clothing Firms In Indonesia
}

\author{
Zulkifli Musannip Efendi Siregar ${ }^{1}$, Suryana ${ }^{2}$, Eeng Ahman ${ }^{3}$ and Syamsul Hadi Senen ${ }^{4}$ \\ \{ zulkiflimusannip@student.upi.edu ${ }^{1}$ \} \\ 1,2,3,4 Universitas Pendidikan Indonesia, Bandung, Indonesia
}

\begin{abstract}
This research aims to know the impact of personality on innovative work behavior of employee in convection firms perspective in Indonesia. The population were employees of the convection of clothing firms in Bandung Indonesia, the case of small and medium enterprises. About 260 questionnaires have been distributed, a total of 249 employees completed the survey questionnaires and returned the questionnaire. The data was analyzed by using Structural Equation Modeling. The results of the study show that personality positively and significantly influences on employee innovative work behavior of convection of clothing firms in Indonesia. The dimension of conscientiousness and agreeableness had the most influence in shaping the variable of personality, while the innovative work behavior of employees most shaped by the idea champion and idea implementation dimensions. If the firms want to recruit new employees, the big five personality traits become important factors that must be considered by the owners of the firms in Indonesia.
\end{abstract}

Keywords: Personality and Innovative Work Behavior

\section{Introduction}

Convection of clothing firm is one of the creative industries that have an important role in the national economy in many countries, especially in Indonesia. Creative industry has become a leading component of economic growth, employment, and innovation in many countries, especially in Indonesia (Hidayat \& Asmara, 2017).

Today, business environments are more complex and competitive, it makes the firms must be more innovative order to survive and meet the needs of the market or its customers (Etikariena \& Muluk, 2014). Also added by Scott, \& Bruce (in Eskiler, Ekici, Soyer, \& Sari, 2016) said that the foundation of high firm performance depends on employees who have innovative behavior in the workplace. Ramamoorthy et al (in Eskiler et al., 2016) also stated that in the era of rapid change, the firms must pay attention and improve the innovative work behavior of employees and Olakitan (2011) said that innovative behavior has a direct and significant influence on business achievements. Innovation has becomes an important key to achieving firms success. Also said by Dess \& Picken, (2000); Tushman \& O'Reilly, 2002 (in Kundu \& Munjal, 2017, p.39) that innovation is very important for organizations to be able to grow, survive in a competitive and fast changing environment. This explanation indicates that if convection of clothing firms wants to survive and succeed in its business, so the firms need employees who have innovative work behavior in workplace. Employees who have innovative work behavior will tend not to be passive in work but actively seek opportunities for new ideas to be applied in the workplace. 
In this research, the authors will look at the role of personality towards innovative work behavior. Personality determines work behavior. An employee who has a good personality tends to work better at work than employees who do not have a good personality at work.

Research conducted by Chen, $\mathrm{Wu}, \&$ Chen (2010) on employees of the maritime tourism industry in China shows that personality traits have a relationship to innovative behavior. They found that all four personality traits significantly influence employee innovative work behavior. Another study by Munir \& Beh (2016) of human resource executives in automotive component manufacturing companies in Malaysia showed differences in results, namely not all personality factors affect innovative work behavior. Only the openness factor has a positive effect on innovative work behavior, while other factors do not have a significant influence on innovative work behavior. The difference of research findings also found by Yesil \& Sozbilir (2013) in their research found that only one dimension influences innovative work behavior namely openness to experience, while the other four dimensions of extraversion, agreeableness, conscientiousness, and neuroticism do not affect innovative work behavior.

Based on the previous explanation, the authors wants to do research on how the personality traits impact on the innovative work behavior of employees in Indonesia with small and medium enterprises categories. The aim of the study is to analyze the influence of personality on employee innovative work behavior.

\section{Literature Reviews}

\subsection{Innovative Work Behavior}

De Jong \& den Hartog (2010) stated that innovative work behavior is individual behavior that intentionally introduces new and useful ideas, work processes, products and procedures in working. Messmann \& Mulder (2012) also states that in the context of modern work, new ideas are needed to increase significant changes in organizations. For example, creating new routines, simplifying the work process, using new work tools, improving both internal and external cooperation, and creating new things in service for clients. Farr and Ford, 1990 (in De Jong \& den Hartog, 2010) described innovative behavior as an employee's behavior aims that initiate and intents to introduce of new and useful ideas, method or procedures in the workplace. Another opinion states that innovative work behavior is all individual action directed at the generation, processing and application /implementation of new ideas about how to do things, including new product ideas, technology, procedures or work processes with the aim of increasing the effectiveness and success of organizational processes (Nijenhuis, 2015). Furthermore, Gaynor (2002, p.57) defines innovative behavior as an individual's action to create and adopt ideas/ideas or new ways to be applied in the execution and completion of work. Whereas, West dan Farr 1989 (in Goller \& Paloniemi, 2017,p.144) stated that the term innovation refers to new products and processes as a result of the development of innovations that are potentially beneficial to the organization.

Messmann \& Mulder (2012) identified four dimensions of innovative work behavior, Opportunity Exploration, Idea Generation, Idea Promotion and Idea Realization. Opportunity exploration means that employees have a concern for the work environment and for the development of current issues, adding insight related to work and participating in many activities outside of organization which are beneficial for the organization. After exploring the opportunities that exist innovative employee behavior will bring new ideas (ideas generation) to be applied placed work, then the idea or idea is championed (idea champion) to be implemented by spreading these ideas and seeking support for the ideas they have, then is application (implementation) which shows how far employees apply new things such as using 
new technologies, procedures, services, systems and methods of work. Also added by De Jong \& Den Hartog (2010) revealed there are four dimensions of innovative work behavior namely idea exploration, idea generation, idea champion, and idea implementation. Idea exploration is a dimension of innovative work behavior where employees are able to find opportunities, find ideas for improving work methods. Idea generation is an innovative dimension of work behavior where employees are able to develop innovative ideas through creating and suggesting ideas for new products, services, and processes. Generally,new ideas arise when employees succeed in exploring ideas. In the idea championing dimension, employees are encouraged to seek support in realizing the new innovative ideas they have produced. In the implementation dimension of the idea, employees have the courage to apply these new ideas to the routine work process that they normally do and try to develop new things in the work.

\subsection{Personality}

Personality has an important aspect in the human behaviour in workplace and personality has five dimensions namely neuroticism, extraversion, employee openness to experience, employee agreeableness, and employee conscientiousness (Yesil \& Sozbilir, 2013). Many personality characteristics and five factors of individual personality are most commonly used to evaluate employee personality. These five factors of individual personality are extraversion, agreeableness, conscientiousness, the stability of emotion and openness (Bhatti, Kaur, \& Battour, 2013).

Openness to experience includes aspects like imagination, intellectual curiosity, and the tendency to reexamine traditional values (Walker and Broyles in Rossberger \& Krause, 2014). Another opinion said that employee who has open to experience are more engage in new and novel experiences and ideas (Rossberger \& Krause, 2014) and such employees who has opennes to experience are more likely to accept new experiences and change in organization which are as critical elements in the innovation process (Woods, Mustafa, Anderson, \& Sayer, 2018). Other opionion said that employee who has openness to experience are intellectually curious, appreciative of art, and sensitive to beauty (Olakitan, 2011).

According to Rothmann \& Coetzer (2003) the conscientious person is purposeful, strongwilled and determined. While, employee who has conscientiousness characterized by having a high achievement orientation, dependability and orderliness. Mount 1991 (in Lotfi, Noorizwan, Muktar, Ologbo, \& Chiemeke, 2016) described conscientiousness as the characteristics of people who are reliable, dutiful, organized, responsible, goal oriented and hardworking.

Employee who has extroversion has a positive emotions, surgency, and enjoy being with people, and usually full of energy (Olakitan, 2011). According to Lounsbury et al., (2012) extraversion can be seen from the trait when an employee more sociable, easy outgoing, gregarious, expressive and talkative. Agreeableness is one of a very important component of social behavior namely interaction among group members, interpersona, and blending with others people (Yang \& Hwang, 2014). According to Barrick and Mount (in Lotfi et al., 2016) stated that agreeableness is one of employee personality dimension as individual characteristics of helpful, decent, courteous, generous and cheerful.

Lotfi et al., (2016) said that neuroticism or emotional stability is a dimension of normal personality indicating the tendency of employee to a negative affects such as feeling of fear, feel sadness, embarrassment, anger, guilt and disgust. Employee who has high neuroticism score characterized that an employee is prone to having irrational ideas, becomes less able to 
control impulses, and coping poorly with stress(Lotfi et al., 2016). A low neuroticism score is characterized by having emotional stability. These employee are usually calm, even tempered, relaxed and able to face stressful situations without becoming upset (Hough et al., 1990 citied by Lotfi et al., 2016).

\section{Methodology}

Sturctural Equation Modeling method was used in analyzing the data in this research. The population in this study were employees in the convection of clothing firms in Bandung Indonesia with small and medium business categories. From 260 questionnaires that have been distributed, a total of 249 employee of convection of clothing firms completed the survey questionnaires.

The item of innovative work behavior in this research use eight scale was adopted from De Jong and Den Hartog (2010) related to the innovative work behavior dimension namely the idea of exploration, employee idea generation, employee idea championing, and employee idea implementation. While personality traits use fourteen item adopted from (Yesil \& Sozbilir, 2013).

\section{Result And Discussion}

\subsection{Result}

\subsubsection{Goodness of Fit Test}

Before further analysis is carried out, it is needed to do a goodness of fit test of the data. The results of the goodness of fit test can be seen in Table 1 below:

Table 1. Goodness of Fit Index Statistics

\begin{tabular}{lccc}
\hline $\begin{array}{l}\text { Goodness of } \\
\text { Fit Index }\end{array}$ & Cut off Value & Result & Decision \\
\hline Cmin/DF & $\leq 2.00$ & 1.998 & Good Fit \\
\hline AGFI & $\geq 0.90$ & 0.847 & Marginal Fit \\
\hline GFI & $\geq 0.90$ & 0.887 & Marginal Fit \\
\hline CFI & $\geq 0.90$ & 0.920 & Good Fit \\
\hline TLI & $\geq 0.90$ & 0.907 & Good Fit \\
\hline RMSEA & $\leq 0.08$ & 0.063 & Good Fit \\
\hline RMSR & $\leq 0.05$ & 0.037 & Good Fit \\
\hline \multicolumn{4}{c}{ Source : The Ouput of AMOS } \\
\hline
\end{tabular}

Based on table 1, we can see that the model in this study has a fit model, so that further analysis can be carried out. Although AFGI and GFI are categorized as marginal fit, other fit test testing criteria show very good results.

\subsubsection{Hypothesis Testing}

The hypothesis proposed in this study is that there is a positive and significant influence on innovative work behavior of employee. Based on the results of the study, in table two show the results of hypothesis testing.

Table 2. Hypothesis Testing

\begin{tabular}{lcccc}
\hline & Relations & Estimate & $\mathrm{P}$ \\
\hline Innovative & $<---$ & Personali &, 854 &, 000 \\
\hline
\end{tabular}




\begin{tabular}{l}
\hline \multicolumn{2}{c}{ Relations } & Estimate & P \\
$\begin{array}{l}\text { Work_Behavi ty } \\
\text { or }\end{array}$ \\
\hline \multicolumn{2}{c}{ Source : The Ouput of AMOS }
\end{tabular}

Hypothesis testing results show that personality has a positive and significant influence on employee innovative work behavior of convection of clothing firms in Indonesia. The estimation results show a value of 0.858 with a probability of 0,000 . The probability value of 0,000 is less than 0.05 so it can be informed that innovative work behavior has a positive and significant influence on innovative work behavior.

\subsection{Discussion}

The results showed that there was a positive and significant influence between personality on innovative work behavior of convection of clothing firms workers in Bandung Indonesia. This result indicate that if the employee's personality is getting better, then the employee tends to be more innovative at work. Conversely, if employees do not have a good personality, then employees will tend to be less innovative in work. It means that the success of clothing convection business in Bandung Indonesia must be supported by the personality of the employees in the firms.

The variable of personality has an estimated value of 0.854 with a probability value of 0.000 and critical ratio value of 6.596 . The probability value of personality not exceed 0.05 and the critical ratio value exceeded 1.967 . So, it can be informed that personality positively and significantly impact innovative work behavior of employee in convenction firms in Indonesia. From the five dimensions of personality that used in this model, conscientiousness and agreeableness were the factors that have the most influence in shaping the personality of employees while the innovative work behavior of employees is most shaped by the idea champion and idea implementation dimensions.

The result of this study was consistent with the previous findings of research conducted by Niu, (2014) that emphasizes modern organizations needs to hire the right people with right personality traits in order for them enhance the innovative capability and personality has significamt impact on behavior of employee(Abdullah, Omar, \& Panatik, 2016). Akhigbe \& Bibiebi (2017) analyze the managerial personality on innovative work behavior of telecomunication firms in Nigeria. They analyze the dimension of extraversion and agreeableness personality trait on innovative work behavior of employee. They found that extraversion and agreeableness of personality trait are significantly influence innovative work behavior of employee.

The output of research result that has been done with the analysis of structural equation modeling shows the results as shown figure 1 below: 


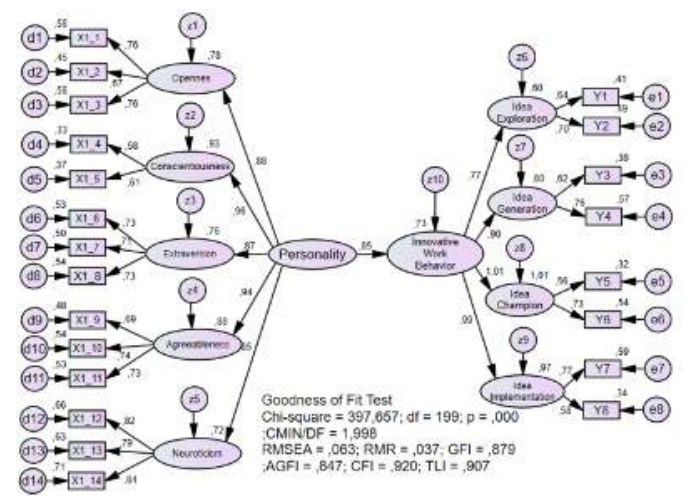

Fig.2. Structural Equation Modelling

\section{Conclusion}

The results show that personality positively and significantly impact employee innovative work behavior in convection of clothing firms in Bandung Indonesia. In other words, personality has an important role in improving innovative work behavior of employee in workplace. The better of employee personality, the employee will be likely to be more innovative at work. Conscientiousness and Agreeableness are the factors that have the most influence in shaping the personality of employees, while the innovative work behavior of employees is most shaping by the idea champion and idea implementation dimensions.

\section{Implication}

The results of the study have implications for managers or business owners of clothing convection, firms in Indonesia. The owners of firms must pay attention to the personality of employees at work. If the firms want to recruit new employees, personality traits become important factors that must be considered by owners or managers of the firms in Indonesia.

\section{References}

[1] Abdullah, I., Omar, R., \& Panatik, S. A. (2016). A Literature Review on Personality, Creativity and Innovative Behavior, 6(1), 177-182.

[2] Akhigbe, O. J., \& Bibiebi, E. L. (2017). Managerial Personality and Innovative Work Behaviour of Telecomunications Firms in Nigeria. International Journal of Economics, Commerce and Management, V(12), 277-300.

[3] Bhatti, M. A., Kaur, S., \& Battour, M. M. (2013). Effects of individual characteristics on expatriates ' adjustment and job performance. European Journal of Training and Development, 37(6), 544-563. https://doi.org/10.1108/EJTD-02-2013-0013

[4] Chen, S.-C., Wu, M.-C., \& Chen, C.-H. (2010). Employee's Personality Traits, Work Motivation and Innovative Behavior in Marine Tourism Industry. Journal of Service Science and Management, 3(2), 186-197. https://doi.org/10.4236/jssm.2010.32024

[5] De Jong, J., \& Den Hartog, D. (2010). Measuring Innovative Work Behaviour. Creativity and Innovation Management, 19(1), 23-36. https://doi.org/10.1111/j.14678691.2010.00547.x

[6] Eskiler, E., Ekici, S., Soyer, F., \& Sari, I. (2016). The relationship between 
organizational culture and innovative work behavior for sports services in Tourism enterprises. Physical Culture and Sport, Studies and Research, 69(1), 53-64. https://doi.org/10.1515/pcssr-2016-0007

[7] Etikariena, A., \& Muluk, H. (2014). Hubungan antara Memori Organisasi dan Perilaku Inovatif Karyawan. Makara Hubs-Asia, 18(2), 77-88. https://doi.org/10.7454/mssh.v18i2.3463

[8] Gaynor, G. H. (2002). Innovation by Design: What It Takes to Keep Your Company on the Cutting Edge. New York: Amacom.

[9] Goller, M., \& Paloniemi, S. (2017). Agency at Work an Agentic Perspective on Profresional Learning and Development. Springer International Publishing AG.

[10] Hidayat, A. R. T., \& Asmara, A. Y. (2017). Creative industry in supporting economy growth in Indonesia : Perspective of regional innovation system. In 3rd International Conferenc of Planning in the Era of Uncertainty (Vol. 12031).

[11] Kundu, S., \& Munjal, S. (2017). Human capital and innovation: Examining the role of globalizaiton. Palgrave Macmillan. https://doi.org/10.1057/978-1-137-56561-7

[12] Lotfi, M., Noorizwan, S., Muktar, B., Ologbo, A. C., \& Chiemeke, K. C. (2016). The Influence of the Big-Five Personality Traits Dimensions on Knowledge Sharing Behavior. Mediterranean Journal of Social Science, 7(1), 241-250. https://doi.org/10.5901/mjss.2016.v7n1s1p241

[13] Lounsbury, J. W., Foster, N., Carmody, P. C., Kim, J. Y., Gibson, L. W., \& Drost, W. A. (2012). Key personality traits and career satisfaction of customer service workers. Managing Service Quality: An International Journa, 22(5), 517-536. https://doi.org/10.1108/09604521211281404

[14] Messmann, G., \& Mulder, R. H. (2012). Development of a measurement instrument for innovative work behaviour as a dynamic and context- bound construct. Human Resource Development International, 15(May 2013), 37-41. https://doi.org/10.1080/13678868.2011.646894

[15] Munir, R., \& Beh, L. S. (2016). Do personality traits matter in fostering innovative work behavior? Social Sciences (Pakistan), 11(18), 4393-4398.

[16] Nijenhuis, K. (2015). Impact Factors For Innovative Work Behavior in The Public Sector. University of Twente.

[17] Niu, H. (2014). Is Innovation Behavior Congenital? Enhancing Job Satisfaction as a Moderator. Personnel Review, 43(2), 288-302. https://doi.org/10.1108/PR-12-20120200

[18] Olakitan, O. O. (2011). An Examination of the Impact of Selected Personality Traits on the Innovative Behaviour of Entrepreneurs in Nigeria. International Business and Management, 3(2), 112-121.

[19] Rossberger, R. J., \& Krause, D. E. (2014). Personality , Culture and Innovation A National Level Analysis. GSTF International Journal of Psychology, 1(1), 74-80. https://doi.org/10.7603/s40790-014-0011-6

[20] Rothmann, S., \& Coetzer, E. P. (2003). The Big Five Personality Dimension and Job Performance. SA Journal of Industrial Psychology, 29(1), 68-74.

[21] Woods, S. A., Mustafa, M. J., Anderson, N., \& Sayer, B. (2018). Innovative work behavior and personality traits Examining the moderating effects of organizational tenure. Journal of Managerial Psychology, 33(1), 29-42.

[22] Yang, L. ., \& Hwang. (2014). Personality traits and simultaneous reciprocal influences between job performance and job satisfaction. Chinese Management Studies, 8(1), 626. 
[23] Yesil, S., \& Sozbilir, F. (2013). An Empirical Investigation into the Impact of Personality on Individual Innovation Behaviour in the Workplace. Procedia - Social and Behavioral Sciences, 81, 540-551. https://doi.org/10.1016/j.sbspro.2013.06.474 